\title{
QUALITY OF RURAL LIFE. EDITORIAL
}

\author{
Antonín Vaishar ${ }^{1}$, Lucie Vidovićová2, Elisabete Figueiredo ${ }^{3}$
}

Received 12 June 2018; Accepted 16 June 2018

\begin{abstract}
The paper discusses the concept of the quality of life and its measuring. It tries to explain its peculiarities in the rural space considering different levels of education, professional activities, mobility, ways of dwelling, access to the social and technical infrastructure. The subjective perception of both urban and rural people to the rural quality of life can be manifested in moving in and moving out. The main shortages of the rural quality of life can be seen (by rural people) in a poor access to the prestigious and well-paid jobs and to a richer social life. The main advantages of the rural way of life are generally evaluated (by urban people) by better access to the nature. A promotion of the local identity is considered as an important tool for improving the rural quality of life (besides of a solution of infrastructural problems), considering the enormous difference among European rural areas of a big differentiation of the European countryside. The last part of the paper summarizes the contributions of the special number.
\end{abstract}

Key words: quality of life, rural way of life, Europe

\section{Quality of life}

It is without exaggeration that the topic of quality of life is the one of the most prominent, if not the most prominent area of research in Global North societies nowadays. The simple Google search generates 2,840,000,000 search results featuring the "quality of life" key phrase in just 0.41 seconds. However, only about seven per cent $(190,000,000$ search results) are connecting the quality of life with "rural", while the "urban" is represented three times more often in such searches. This special issue of European Countryside aims to help to address this gap with a special focus on the various aspects of the quality of life in rural areas across Europe.

The issue of quality of life is very complex and no consensual definition has been reached so far. The introductory parts of the papers looking into the quality of life would mention the rising popularity of the term, as well as its relative novelty, interdisciplinarity, multidimensionality, complexity, rising tendency to defragmentation and even controversality and difficulty to grasp, operationalise, and measure this concept. Some will argue that the results of any particular measurement of the quality of life can be assessed only in relation to methods, methodologies and research tools used and no concluding remarks on the general life quality levels should not

\footnotetext{
${ }^{1}$ Doc. RNDr. Antonín Vaishar, CSc., Department of Applied and Landscape Ecology, Faculty of AgriSciences, Mendel University in Brno, Zemědělská 1, 61300 Brno, Czechia; e-mail: antonin.vaishar@mendelu.cz

2 Mgr. Lucie Vidovićová, Ph.D., Office for Population Studies, Faculty of Social Studies, Masaryk University, Joštova 10, Brno 602 00, Czech Republic; e-mail: Lucie.Vidovic@seznam.cz

${ }^{3}$ Ass. Prof. Elisabete Maria Melo Figueiredo, Department of Social, Political and Territorial Sciences, University of Aveiro, Campus Universitário de Santiago, 3810-193 Aveiro, Portugal; e-mail: elisa@ua.pt
} 
be made (Dragomirecká, Škoda, 1997a). And yet probably we all as social actors have this gut feeling on basis which we are able to say whether we have or do not have desired levels of quality of life we envision.

Quality of life (QoL) is considered to have both subjective and objective dimension. Some argue it is related more tightly to health (Carta et al., 2012), others see it a s function of a living conditions (Heřmanová, 2012), or encompassing individual well-being as well as the quality of public services and quality of the society (Gstrein et al., 2017) and another equal the quality of life with general satisfaction as a cognitive state and distinct from the happiness as a more of an affective state (Hagherty et al., 2001). Dragomirecká and Škoda (1997b) have proposed a short catalogue of types of definitions: 1) quality of life defined by other term(s), such as wellbeing, happiness and satisfaction 2) definitions aiming at one particular aspect such as subjective evaluations of life situation 3) complex definitions looking at interrelationships between characteristics of quality of life such as the size of discrepancy between fulfilled and unfulfilled needs and expectations 4) definitions using the listings of areas where quality of life should be observed such as physical wellbeing, material security (income, housing), cognitive wellbeing (satisfaction), and social wellbeing (relationships); further, there are 5) definitions aiming at "objective" descriptions of individual wellbeing steaming from satisfaction or dissatisfaction in subjectively important life domains and last but not least there are 6) model approach to of quality of life where different aspects and domains feed into each other in particular ways of influence. In classical example by Lehman, Ward and Linn (1982), the model features individual characteristics which feed into subjective indicators of QoL in different life dimensions and put together with objective indicators of QoL produce the overall satisfaction. The stress on subjective measures and fluid concept of satisfaction is based on the empirical studies where subjective measure are better predictors than objective ones.

We see the merit especially in the model approach to defining the quality of life, as it enables to take into consideration both individual level characteristics, the social and physical surrounding environments as well as more general frameworks within which these forces operate. D'Agostini and Fontini (2008) provide quite useful distinction between measuring the quality of life and the quality of living environments which are interrelated ("cannot be dissociated but they are distinct" (ibid. p. 488), yet could be subject to separate efforts and interventions. In the authors words "the quality of life should inform about the level of satisfaction of people who are living under given conditions..., on the other hand the quality of living conditions is information on the possibility that many or few declare to be living well" (p. 488). This approach helps to promote the conditions which are collectively perceived as important to the human satisfaction and several papers in this special issue illustrate how these processes (should) operate in Europe.

\section{Particularities of the rural quality of life}

Coming out from the presupposition about subjective and objective aspects of the quality of life, we can pronounce the following starting points to differ the rural way of life from the urban one: [1] the subjective part of the rural quality of life (rural well-being) depends - similarly as the way of life on many factors, the education level being the most important among them [2] the objective part of the rural quality of life is linked mostly with technical and social infrastructure. Rural quality of life relates to the countryside as a lived space, which can be defined as a subjective construction through everyday life, meanings, symbols and values (Kivitalo, Kumpulainen and Soini, 2015).

Except of suburbia, the education level of rural population is generally lower than of the urban one (Schafft, 2016). This fact has some important consequences, concerning the quality of life. The transition of rural people (employed frequently in the industry and agriculture) from the productive to the consumable way of life is slower. Their life strategies are less career-oriented and by this way it is less stressful. Their wages are lower as a rule. The gender aspect marks also some differences. Less educated women record higher fertility rate which signals a little bit higher orientation to the family in comparison with the urban population. On the other side, rural people have a house of its own and a piece of land as a rule which forms their stronger relation to 
the landscape, village, region. Rural milieu is also characterized by a higher level of social control, which predicts a higher personal security but limits an independence and freedom.

Whereas the technical infrastructure of rural settlements starts to be comparable with the urban technical infrastructure in many parameters, the social infrastructure still divides urban and rural settlements quite substantially (Vaznoniené and Pakeltiené, 2017). Existence of schools, physicians, shops, post offices and other facilities depends on the number of customers, it means on the number and structure of inhabitants. Increasing mobility of people opens a competition of local facilities with those in better equipped central places. A solution for this problem is often related with the promotion of better and frequent public transportation.

The public transportation in rural areas under market conditions is usually inefficient due to low density of travellers. Thus, the connections are often cancelled or less frequent. Less frequent public transportation means a decrease of interest from the citizens resulting in next cancellation of connections as a vicious circle. Satisfactory public transportation is possible only as a public service supported by the state (regions, municipalities etc.). A proven solution is seen in the creation of regional integrated public transportation systems that will bring customers back to buses and trains to reduce the financial losses of carriers (Št'astná and Vaishar, 2017). The difficulties in public transportation lead to the re-orientation of villagers for the use of private cars. It seems to be comfortable but by such a way a part of rural residents -who are not able to drive or who do not own a car-become excluded: superannuated, disabled, very poor, teenagers, family partners (in the case of the only one car in the family).

The technical infrastructure can influence the rural quality of life in two directions. Firstly, it is connected with a level of (dis)comfort. Secondly, lacking infrastructure can impact on the environment negatively (e.g. exhalations from local heating, discharge of polluting water, the problem of solid waste etc.). Whereas earlier solid, liquid and gaseous wastes have been scattered in nature and can be decomposed, at the present time, the massive application of chemicals and plastics poses serious problems, even in smaller quantities, in rural areas.

A closer connection of rural people with nature is believed to be one of the most important characteristic and advantages of the rural quality of life. However, we are not convinced about it. It seems that it follows rather an idealization of urban people about the countryside (Figueiredo, 2009). On the contrary, it seems that the villagers rather seek for urban achievements. On the other side, urban dwellers are attracted by the rural nature within both second and permanent housing. In the same vein, rural areas are increasingly demanded and consumed, through tourism related activities, by urban populations (e.g. Figueiredo, 2013; Eusébio et al., 2015; Carneiro et al., 2017)). By such a way, villages are becoming to be targets of the amenity migration which means migration motivated by improving the quality of life of urban residents (Tulla et al., 2017). Otherwise, a better access of villagers to the nature is also questionable. For example, the value of the coefficient of the ecological stability in towns of the fertile South-Moravian Region is, according to our calculations, more favourable than the same indicator in the villages of the region with large areas of arable land.

Individual subjective aspects of the quality of life can be evaluated according to motivations for moving in or moving out. It seems that the main motivations of the emigration of rural people (especially the young and educated ones) from the countryside are the lack of prestigious and well-paid jobs and lack of the social infrastructure of a higher level and related lack of an intensive social life. Too hard social control can be the third (much weaker) reason (e.g. Vaishar and Pavlü, 2018). These factors are inseparably linked with the countryside. An efficient commuting is the only possibility to eliminate them at least partly. Why people stay in the countryside? Many of them are connected with a house, the landscape, relatives and friends. The others can be simply passive staying in their villages due to inertia. It seems that people in peripheral rural areas are often reconciled with the situation.

The mentioned differences and specifics of the rural way of life lead to different consequences which can be perceived both positively and negatively. They can manifest both in emigration from and immigration into the countryside. Young and educated people leave the countryside searching for prestigious and well paid jobs, rich cultural and social life and an anonymous - seemingly free- way of life. Concerning the immigration of urban dwellers to the countryside, 
Kala et al. (2016) mention four motivations: distaste for city, idealisation of a nicer life, a living in freedom and a return to roots. Recent back-to-the-countryside movements in Southern European contexts (e.g. Greece and Portugal) have also been marked by economic reasons, due to the financial crisis and to the existence of family properties in rural areas (e.g. Figueiredo, Partalidou and Koutsou, 2018). Rural areas offer a relatively quiet milieu, an easier way of life and also a cheaper dwelling as a rule. Stockdale (2015) shows on the British example, that urbanto rural migrants are hardly looking for activities in the primary sector. They are engaged rather in retail or arts and crafts. However, regarding the recent relocation movements in Portugal and in Greece, frequently people engage in agricultural activities, benefiting, as well, from European Union programmes (e.g. Young farmers' programmes. All in all, rural migration is a very complex feature including different directions, motivations consequences and impacts on places of both sources and targets of migration (Bock, Osti and Ventura, 2016).

Objective indicators of the quality of life (Diener and Suh, 1997) can be divided into social (like access to health and social care, education or jobs) and economic ones (like an average income), whereas environmental indicators are related more to the maintenance of the nature than to the human's quality of life. Although the particular values are different in various European countrysides, rural areas pull a shorter rope as a rule. However, subjective factors seem to be decisive for the evaluation of the quality of life by public and for their residential preferences.

In the frequent medical literature, rural quality of life is connected usually with the rural health care and its accessibility (which is an infrastructural aspect), further with the labour in agriculture as a medical aspect (e.g. Donham and Thelin, 2016 and many others), psychological aspects of the rural life (spiritual well-being), and with the rural milieu which is important for a treatment of various diseases. It is possible to speculate that the health-related quality of life is worse in rural areas in comparison with urban and suburban ones (due to the access to the medical care). However, rural seniors can have usually worse characteristics of physical health but better characteristics of the mental health in this comparison (Weeks et al., 2004).

In the literature, rural quality of life and rural well-being is still connected with agriculture (Smith et al., 2018). Its structure is sometimes perceived (similarly with the one of sustainability) as a complex of social, economic and environmental factors. Rural life and agricultural activities start to be used for improving of the quality of life within the so called green care or social farming (e.g. Leck, Evans and Upton, 2014). Agriculture contributes to improving the quality of rural life also through the change of its character from the purely productive to a multifunctional activity including the environmental function, food security etc.

In some countries, rural change is connected also with the immigration of bigger amounts of foreign workers or ethnically and/or religiously diverse people (Morén-Alegretand Solana, 2004). They are often illegal, included into the black or grey economy with limited rights or they are fully dependent on a social assistance without any interest in taking part in local economy neither in social life; they come sometimes with a basic education or are even illiterate. Whereas cities are able to absorb certain number of such immigrants, the incomers may represent a foreign and disturbing element in the more conservative countryside and thus they impact on the rural quality of life mainly in a negative sense. In the same vein ideas about a dispersal of immigrants from Africa and Asia into European rural areas with the aim to stop their depopulation (Hedberg and Haandrikman, 2014 or Machold and Dax, 2016) may also be seen as problematic. Individual European countries are at a different stage of transformation from productive to the postproductive agriculture (Almsted et al., 2014). In some cases, the transformation is taking place either by processes of change or by administrative decisions (collectivization). The perception and indicators of rural quality of life (e.g. Somarriba Arechavala, Zarzosa Espina, and Pena Trapero, 2015) have also changed in these countries. However, only a part of the quality of life dimensions can be measured. Many changes have rather a mental character. The countryside is no longer depending on agriculture. Whereas the work in agriculture was a sense of the life in rural areas earlier, it is the source of earning money for consumption at the present time Rural people are looking for a satisfaction of their demands not in labour but in the free time, hobbies, wellness, entertainment and so on. The migration for jobs tends to be substituted with the migration for quality of life. 
In the countries where the mentioned transformation just occurs, it is usually connected with serious problems - loss of the previous sense of life and values of peasants, rural unemployment, abandonment of the native land (van der Zanden 2017), especially of young people who do not fulfil expectations of their parents, rural depopulation, rural poverty, rural exclusion and so on. Although these changes towards the post-productive society are inevitable and in principle positive (because they are bringing modernization to the countryside and therefore an improvement of the quality of life from the long-time view), they are perceived sometimes as a tragedy. This is necessarily reflected in the perception of the rural quality of life at the moment.

Individual European "countrysides" vary ethnically, historically, naturally, from the viewpoint of the geographical position. Also individual characteristic can play their roles. That is why, together with characteristics following general trends, also regional and individual aspects should be taken into account when evaluating the quality of rural life.

An improvement of the rural quality of life can be found in strategies of rural development on regional, national and European levels. The measures are directed to an improvement of rural infrastructure, in a support of rural identity, motivation and participation and to a support of cultural, social and sport activities. LEADER (Dax, Strahl and Kirwan, 2016) based on the community lead local development (Pisani et al., 2017) is the leading programme of the 2013 2020 period for many rural areas. The competition of the "Village of the year" is an example of the motivation in the Czech conditions (Pospěch, Spěšná and Staveník, 2015). The problem is that the financial support is able to improve of some, mainly "objective", aspects of the quality of life. The sustainability of such an improvement after finishing the financial support can be questionable. Sometimes, the financial support can be demotivating as it does not support any search for endogenous solutions.

In the globalized society, rural areas keep local and regional identity and according to Brown and Schucksmith (2016), they can hold up a mirror to society to foster public deliberation and debate about what we understand to be a "good society" and a "good life".

\section{Examining rural quality of life through different approaches and dimensions of analysis}

This special issue on European Countryside is based on a selection of papers dealing with distinct dimensions of rural quality of life, using a diverse set of theoretical and methodological approaches and referring additionally to particular cases from diverse geographical and cultural contexts.

Indeed, studies looking at distinct themes within the main topic of rural quality of life, from diverse scientific perspectives, reveal specific and different realities in Norway, Finland, Poland, Austria, Lithuania, Germany and Czechia. The papers presented in this special issue may be aggregate in some common topics: comparative analysis of rural and urban areas in terms of quality of life; the exploration and examination of diverse indicators of quality of life in rural areas; social and institutional perceptions regarding quality of life in rural settlements; analysis of the role of social infrastructure services, as well as the analysis of the quality of life concerning specific dimensions, such as poverty, and specific social categories, such as older people.

Dealing with standards of living and quality of life indicators in distinct types of rural areas, Brambert and Kiniorska analyse the spatial diversification of those dimensions taking into account the differences between areas in the vicinity of large urban centres and the more remote rural contexts. Using information from the Local Data Bank of the Central Statistical Office of Poland, and diverse sets of data from projects co-financed by European Funds, a quantitative and graphical approach, deriving from the evaluation based on the Perkal's synthetic index with 12 variables related with demographic and economic aspects, within a 10 years' time frame, the authors conclude that the standard of living in Poland is extremely diversified in terms of spatial distribution. Brambert and Kiniorska analysis demonstrate a strong connection between socio-economic development of the different rural territories and the diversity of standards of living, which is also very often connected with processes of industrialization and urbanization of those territories. The authors conclude that the growth of disparities in socio-economic 
development poses some challenges in terms of improvement of the quality of life in the most remote rural settlements.

The paper presented by Michalska-Żyła and Marks-Krzyszkowska also analyses the relationship of quality of life and quality of living in Polish rural communities with distinct levels and patterns of socio-economic development. Drawing from both objective and subjective data and indicators regarding the quality of life and the quality of living, the authors conclude that the rural residents who have participated in the study reveal a high level of satisfaction with their life, motivated first and foremost by family relationships. The dissatisfaction motives are related mainly with the financial constraints. The study undertaken in different rural areas of Poland, also reveal that - regarding their subjective assessment of quality of living - residents made a very positive evaluation of their communities, mainly related with the natural environment and safety. On the contrary, the lack or the scarcity of technical infrastructures, transportation and the reduced opportunities to be engaged in the community political life and decisions, seem to be the main factors of dissatisfaction among the ones surveyed. Despite these general trends, authors point the difficulties in finding general correlations that may support and clarify the relationship between quality of life and quality of living in rural communities, also stressing the diversity of situations across Poland.

The relevance of social infrastructure for the local communities' well-being is the main topic examined by Vaznonienè and Kiaušienè based on the results of a questionnaire directed to residents in five rural municipalities of Lithuania, regarding their opinions on the need of social infrastructures (SI) services and the type of organizations needed in order to improve their quality of life. Based on the assumption that SI may be seen as an important factor to foster the capabilities of a given community, improve life satisfaction and create better opportunities for integration and engagement in society, the authors argue that the role of SI in improving wellbeing should be evaluated more carefully, as the empirical evidence gathered in this study demonstrate that SI services play indeed a significant role in improving quality of life, as well as people's perceptions and feelings regarding their living environments and its future. The need to design effective SI services based on the reconciliation between 'top-down' and 'bottom-up' approaches, taking into account a diversity of actors and agents is also pointed out by Vaznonienè and Kiaušienè as an important step to improve the well-being of local communities.

The political and policy dimensions and measures are object of the analysis undertake by Moser, Peter, Fengler and Strohm-Lömpcke, specifically regarding European Union's strategic priority of improving quality of life and the guidelines concerning rural development programmes (RDP's) and its application in Germany. The authors stress that due to the federal structure of Germany, each federal state is responsible to implement RDP's and, as each state has taken a distinct approach in enhancing quality of life in rural areas, the consequences of such programmes tend to be diverse. The authors use the multidimensional concept of quality of life as a tool to evaluate selected RDP's in Germany in a more theoretical-oriented study, although utilizing some particular cases as examples. Based on a document analysis of RDP's (programme analysis) Moser, Peter, Fengler and Strohm-Lömpcke analyse the measures directly related to the quality of life and their anticipated effects. Concomitantly, an incidence analysis was used to examine the regional distribution of subsides and the multiple aims of the funding with the main objective of analysing the correlation between distribution of funds and the disadvantages in quality of life dimensions. Finally, the authors performed an impact analysis in which they combine the results of the evaluation of the measures with the dimensions of quality of life, assessing them in relation to the available financial information. Results demonstrate that the improvement in quality of life realized through RDP's was distinct in different areas and, generally, with very faint results. In fact, as demonstrated by the analysis, compared with other instruments in Germany, the RDP's are generally of little relevance regarding quality of life improvement. However, there were positive effects regarding certain aspects, as conditions in residential locations and personal activities, as well as, specifically in the example presented - Mecklenburg-Western Pomerania - in focusing on issues as employment and public services that contributed to close the gap in dealing with specific problems related to rural development.

Also Halonen and Kattilakoski analyse the political and policy dimensions and measures to promote well-being and improving quality of life in sparsely populated rural areas, but at 
the municipal level. The authors examine specifically the involvement and engagement of the rural residents of North Karelia region, in Finland, in the measures of well-being undertaken by local authorities, based on interviews directed to municipal representatives. Several dimensions of well-being are analysed in the paper, especially mobility, services, population involvement and participation, as well as their connection to the social inclusion of marginalized rural inhabitants. The authors conclude that, despite the diversity of situations within the region, relational inclusion and active participation seem to be extremely relevant in planning and decision-making regarding the promotion of well-being in rural communities. However, the paper points out the important question of the representativeness and inclusion of those that are not able (due to distinct constraints) to participate in those processes, highlighting the often thin line between participation and social inclusion in political and policy measures of promoting well-being and quality of life in sparsely populated rural areas.

Fischer and Born analyse the perceptions and evaluations of rural poverty held by the mayors of 40 municipalities in Austria that may be qualified as structurally very fragile rural environments. As in the previously mentioned paper, from Finland, also Fischer and Born take into account the relationship between diverse levels of civic engagement and the ability to be represented in the social inclusion policies and measures. Authors combine spatial related aspects of poverty and quality of life in rural areas with the perception and evaluation of the mayors interviewed. Poverty and deprivation in rural areas is difficult to measure and to address, as statistical data is scarce, on the one hand and social 'hiddenness' of the phenomenon do exist. These facts tend to obstruct an objective and clear view of poverty and marginalization and, consequently, the design of adequate policies and measures to address these social problems. The authors, although stressing the impossibility in generalizing results, point out several limitations related to political dealing with marginalization and poverty in weak rural areas, setting the context for a much needed reinterpretation of public measures and services regarding social inclusion and well-being in marginalized rural contexts. One of the major limitations identified relates to the fact that poverty and material deprivation are not represented in the political agenda when it comes to very weak rural municipalities and small towns, drawing the attention for the need to develop new approaches for these contexts. Other important aspect is related to the often fragmented character of public welfare policies that needs to be revised, as deprivation demands, frequently, a holistic approach. Also a quality of life approach should be taken regarding poverty and deprivation, as it allows unveiling spatial differentiations in the quality of life itself and also regarding coping strategies. Once these strategies and possible support networks are identified it would be easier to render visible these situations and find the most adequate policies and measures to improve well-being and quality of life for all.

The paper presented by Bernard also examines indicators of poverty, opportunity deprivation and satisfaction, by comparing quality of life in rural and urban settlements in Czech Republic. The paper presents three innovative approaches to address rural quality of life. The first one explores the need to go beyond the traditional rural-urban dichotomy by introducing a rural territorial differentiation that affects the quality of life. The second is based on two distinct spatial patterns of diverse forms of rural territorial disadvantage. As the author stresses, while areas with growing processes of social exclusion are negatively affected by limited employment opportunities, remote rural areas are more often affected by opportunity deprivation in terms of access to services. Finally, the third innovative element is related to the net-effect of the residential environment. Based on a survey conducted in different types of territorial contexts, from urban ones to peripheral rural areas, the author concludes that there is a growing process of opportunity deprivation in rural areas that is not accompanied by a decrease in the levels of satisfaction with the community. Furthermore, results show that the differences between rural areas are larger than the difference between rural and urban contexts. Accordingly with Bernard, these conclusions contradict recent Czech public authorities' narratives about small rural areas poverty and quality of life, mainly and firstly because, as the author states, it is not the size of a community that determines its quality of life and, secondly, because poverty and job search do not seem to be the specific rural problem in Czech Republic, as access to services (from job related to shops) seems to be a much more pressing issue. 
The last two papers presented in this Special Issue deal with a specific social category, often predominant in rural contexts - older people - although exploring distinct but interrelated questions. Blekesaune and Haugen examine the satisfaction of older people with local services, comparing rural and urban communities. Petrová-Kafková, Vidovićová and Wija analyse older people perceptions and engagement regarding the performance of local governments in rural areas. Blekesaune and Haugen base their reflections and conclusions drawing from the results of two national surveys of the residents of municipalities in Norway. They compare the level of satisfaction of older people in rural and urban municipalities regarding the availability of services as well as the involvement in the community. The paper explores the living conditions and factors conditioning quality of life and well-being. Results from the quantitative analysis of the data gathered by the two mentioned surveys, demonstrate that, contrary to the general assumptions, rural inhabitants present similar levels of satisfaction with medical services and home care to their urban counterparts. This similarity is the result, authors argue, of Norway's policies of social welfare in sparsely populated areas. In comparison with urban residents, rural inhabitants demonstrate also, as expected, more frequent social interactions with neighbours, as well as higher levels of participation in voluntary work. However, the relationship between rural and urban residence and satisfaction of older people is not possible to entirely determine from the data analysed. The authors point out the need of further qualitative studies to better demonstrate that relationship and to provide a more detailed picture on this topic.

Petrová-Kafková, Vidovićová and Wija, as already mentioned above, examine, based on a representative survey applied, in 2016, to older people in Czech Republic, their civic engagement and political participation, as well as their perceptions regarding the performance of local governments in rural areas. The starting point of their reflection is a dichotomic assumption: on the one hand the argument that older people represent a major driver of social and political transformation in contemporary and democratic societies, expressed by the notion of 'grey power'; on the other hand, the argument of social exclusion of older persons and of the oppression of their voices and needs. Based on the analysis of the empirical data, authors state that there is no easy answers to the question - or the dilemma - whether 'grey power' or threatened agency would best describe the older ruralities engagement. In fact, results show a rather low level of older people participation and civic engagement in small municipalities and rural areas. It even seems to have decreased, in comparison with previous studies, although these differences may be attributed to distinct methodological procedures. Nevertheless, the results demonstrate that older people wish to be informed about local issues and, sometimes, actively search for information. Sociodemographic variables are relevant here, as the younger senior citizens and those with higher literacy levels tend to play a prominent role in the community life, more often engaging in political activities and functions. Furthermore, results show that there is a clear relationship between political involvement and membership in voluntary associations. Results from the study of Petrová-Kafková, Vidovićová and Wija also demonstrate that older people in rural areas tend to express high levels of place attachment - an important variable in explaining civic engagement as well as satisfaction with life in the community.

The contributions selected to be part of this special issue shed some light on the topic of rural quality of life and raise important questions regarding its very complex and multidimensional character. Yet, no definitive answers are given regarding the factors, indicators and dimensions underlying and involved in rural quality of life. Based on the cases and dimensions explored in each paper, we believe that many variables are at stake when it comes to debate what should constitute the quality of life in rural areas, mainly giving the diversity of rural contexts and regional situations. However, it is unquestionable the added value the here presented papers represent to the debate on quality of life in rural territories, by the examination of distinct factors, contexts and cases from different perspectives. We believe that these contributions may constitute relevant references and inspiration to other scholars interested in the topic, contributing to identify and define important concepts, indicators, dimensions and methodologies. 
[1] Almsted, Å., Brouder, P., Karlsson, S. \& Lundmark, L. (2014). Beyond post-productivism: from rural policy discourse to rural diversity. European Countryside 6(4), 297-306. DOI: 10.2478/euco-2014-0016.

[2] Bock, B., Osti, G. \& Ventura, F. (2016). Rural migration and new patterns of exclusion and integration in Europe. In Schucksmith, M. \& Brown, D. L., eds., Routledge International Handbook of Rural Studies (not paged). Abingdon: Routledge.

[3] Brown, D. L. \& Schucksmith, M. (2016). A new lens for examining the rural change. European Countryside 8(2), 183-188. DOI: 10.1515/euco-2016-0015.

[4] Carneiro, M. J., Eusébio, C. \& Caldeira, A. (2017). The Influence of Social Contact in Residents' Perceptions of the Tourism Impact on Their Quality of Life: A Structural Equation Model, Journal of Quality Assurance in Hospitality \& Tourism, 19:1,130. DOI: 10.1080/1528008X.2017.1314798.

[5] Carta, M. G., Aguglia, E., Caraci, F., Dell'Osso, L., Di Sciascio, G., Drago, F., Del Giudice, E., Faravelli, C., Hardoy, M. C., Lecca, M. E., Moro, M. F., Calò, S., Casacchia, M., Angermeyer, M. C. \& Balestrieri, M. (2012). Quality of Life and Urban / Rural Living: Preliminary Results of a Community Survey in Italy. Clinical Practice and Epidemiology in Mental Health 8, 169-174. DOI: 10.2174/1745017901208010169.

[6] D'Agostini, L. R. \& Fantini, A. C. (2008). Quality of Life and Quality of Living Conditions in Rural Areas: Distinctively Perceived and Quantitatively Distinguished. Social Indicators Research, 89(3), 487-499. DOI: 10.1007/s11205-008-9245-4.

[7] Dax, T., Strahl, W. \& Kirwan, J. (2016). The LEADER programme 2007-2013: Enabling or disabling social innovation and neo-endogenous development? Insights from Austria and Ireland. European Urban and Regional Studies 23(1), 56-68. DOI: $10.1177 / 0969776413490425$.

[8] Diener, E. \& Suh, E. (1997). Measuring quality of life: economic, social and subjective indicators. Social Indicators Research 40(1-2), 189-216. DOI: 10.1023/A:1006859511756.

[9] Donham, J. \& Thelin, A. (2016). Agricultural Medicine: Rural Occupational and Environmental Health Safety $2^{\text {nd }}$ ed. Hoboken: John Wiley.

[10] Dragomirecká, E. \& Škoda, C. (1997a). Kvalita života. Vymezení, definice a historický vývoj pojmu v sociální psychiatrii. Česká a Slovenská Psychiatrie 93(2), 102-108.

[11] Eusébio, C., Carneiro, M. J., Kastenholz, E. \& Alvelos, H. (2015). Social tourism programmes for the senior market: a benefit segmentation analysis, Journal of Tourism and Cultural Change, 15:1, 59-79. DOI: 10.1080/14766825.2015.1117093.

[12] Figueiredo, E. (2009). One rural, two visions - environmental issues and images on rural areas in Portugal. European Countryside, Vol. 1(1), 9-21. DOI: 10.2478/v10091-009-00028.

[13] Figueiredo, E. (2013). McRural, No Rural or What Rural? - Some reflections on rural reconfiguration processes based on the promotion of Schist Villages Network, Portugal. In: Silva, L. \& Figueiredo, E., eds., Shaping Rural Areas in Europe - Perceptions and Outcomes on the Present and the Future (pp. 129-146), Springer: Dordrecht. DOI: 10.1007/978-94-007-6796-6_9.

[14] Gstrein, M., Mateeva, L., Rodiga-Laßnig, P., Abbott, P. \& Wallace, C. (2017). European Quality of Life Survey 016: Quality of Life, quality of public services, and quality of society. Luxembourg: Publication Office of the European Union. DOI: 10.2806/37653.

[15] Hagerty, M., Cummins, R., Ferriss, A., Land, K., Michalos, A., Peterson, M., Sharpe, A., Sirgy J. \& Vogel, J. (2001). Quality of Life Indexes for National Policy: Review and Agenda for Research. Social Indicators Research 55(1), 1-96. DOI: 10.1023/A:101081131. 
[16] Hedberg, C. \& Haandrikmann, K. (2014). Repopulation of the Swedish countryside: Globalization by international migration. Journal of Rural Studies 34, 128-138. DOI: 10.1016/j.jrurstud.2014.01.005.

[17] Heřmanová, E. (2012). Koncepty, teorie a měření kvality života. Praha: Sociologické nakladatelství.

[18] Kala, L., Galčanová, L. \& Pelikán, V. (2016). Dential preferences in the context of voluntary simple lifestyles: What motivates contemporary Czech simplifiers to reside in the countryside? Human Affairs: Post-Disciplinary Humanities and Social Sciences Quarterly 26(4), 410-421. DOI: 10.1515/humaff-2016-0035.

[19] Kivitalo, M., Kumpulainen, K. \& Soini, K. (2015). Exploring culture and sustainability in rural Finland. In Dessein, J., Battaglini, E. \& Horlings, L., eds., Cultural Sustainability and Regional Development (pp. 94-107). Abingdon: Routledge.

[20] Leck, C., Evans, N. \& Upton, D. (2014). Agriculture - who cares? An investigation of "care" farming in UK. Journal of Rural Studies 34, 313-325. DOI: 10.1016/j.jrurstud.2014.01.012.

[21] Lehman, A. F., Ward, N. C. \& Linn, L. S. (1982). Chronic mental patients: The Quality of Life Issue. American Journal of Psychiatry, 139(10), 1271-1276. DOI: 10.1176/ajp.139.10.1271.

[22] Machold, I. \& Dax, T. (2016). Migrationen und Integration: Anstoßzur sozio-kulturellen Veränderung ländlicher Regionen durch internationale Migration. Europa Regional 24(34), 62-76.

[23] Morén-Alegret, R. \& Solana, M. (2004). Foreign immigrants in Spanish rural areas and small towns: current situation and perspectives. Finisterra 77, 21-38. DOI: 10.18055/Finis 1559.

[24] Pisani, E., Franceschetti, G., Secco, L. \& Christoforou, A., eds. (2017). Social capital and local development. Basingstoke: Palgrave Macmillan. DOI: 10.1007/978-3-319-54277-5.

[25] Pospěch, P., Spěšná, D., Staveník, A. (2015). Images of a good village. A visual analysis of the rural idyll in the "Village of the Year" competition in the Czech Republic. European Countryside 7(2), 68-86. DOI: 10.1515/euco-2015-0005.

[26] Schafft, K. A. (2016). Rural education as rural development: Understanding the rural schoolcommunity well-being linkage in a $21^{\text {st }}$-century policy context. Peabody Journal of Education 91(2), 137-154. DOI: 10.1080/0161956X.2016.1151734.

[27] Smith, G. R., Strachan, G., Gibbon, D. (2018). Rural well-being: the push and pull and the diversity in-between. International Journal of Sustainable Development \& World Ecology, in print. DOI: 10.1080/13504509.2018.1446369.

[28] Somarriba Arechavala, N., Zarzosa Espina, P. \& Pena Trapero, B. (2015). Social Indicators Research 120(2), 323-343. DOI: 10.1007/s11205-014-0595-9.

[29] Št'astná, M. \& Vaishar, A. (2017). The relationship between public transport and the progressive development of rural areas. Land Use Policy 67, 107-114. DOI: 10.1016/j.landusepol.2017.05.022.

[30] Stockdale, A. (2015). Contemporary and 'messy' rural in-migration processes: Comparing counterurban and lateral rural migration. Population, Space and Place 22(6), 599-616. DOI: 10.1002/psp.1947.

[31] Tulla, A. F., Valentina-Stoica, I., Pallarès-Blanch, M., Zamfir, D. (2017). Can naturbanization promote environmentally friendly built-up areas? A comparison between Cadí-Moixeró (Catalonia, Spain) and Comana (Romania) natural parks. European Countryside 9(4), 679709. DOI: 10.1515/euco-2017-0039.

[32] Vaishar, A. \& Pavlů, A. (2018). Outmigration intentions of secondary school students from a rural micro-region in the Czech inner periphery: a case study of the Bystrice nad Pernštejnem area in the Vysočina region. Acta Universitatis Carolinae Geographica 53(1), 49-57. DOI: 10.14712/23361980.2018.5. 
[33] Vaznoniené, G. \& Pakeltiené, R. (2017). Methods for the assessment of rural social infrastructure needs. European Countryside 9(3), 526-540. DOI: 10.1515/euco-2017-0031.

[34] Weeks, W. B., Kazis, L. E., Shen, Y., Cong, Z., Ren, X. S., Miller, D., Lee, A. \& Perlin, J. B. (2004). Differences in health-related quality of life in rural and urban veterans. American Journal of Public Health 94(10), 1762-1767.

[35] Zanden van der, E. H., Verburg, P. H., Schulp, C. J. E. \& Verkerk, P. J. (2017). Trade-offs of European agricultural abandonment. Land Use Policy 62, 290-301. DOI: 10.1016/j.landusepol.2017.01.003. 